\title{
Working Capital Management and Corporate Profitability: Empirical Evidences from Nepalese Manufacturing Sector
}

\begin{abstract}
This research paper attempts to fill the gap regarding the working capital management of manufacturing firms in context of Nepal by providing empirical evidence, and moreover, this study act as foundation for future research activity because there are very few working capital management research literatures in Nepalese context. The secondary data for data analysis are retrieved from annual reports of five manufacturing firms for eight-year period from 2010/11 to 2017/18. This study examines the impact of different working capital components, i.e. inventory conversion period, receivable conversion period, payable deferred period, cash conversion cycle, debt ratio and current ratio, with profitability of a manufacturing firm, where profitability is represented by return on equity, return on assets and net income. Statistical tools used for data analysis are Pearson's correlation, ordinary least square regression and binary logistic regression. Such that, this study found that, inventory conversion period, payable deferral period and cash conversion cycle are inversely related with the profitability of manufacturing firms, whereas, receivable conversion period, debt ratio and current ratio are positively related.
\end{abstract}

Keywords: Working capital components, ROE, ROA, OLS regression and Binary Logistic regression

\section{Introduction}

Working capital management can be defined as the management of current assets and current liabilities, and financing the current assets by the combination of short term and long term debt (Raheman \& Nasr, 2007; Falope \& Ajiore 2009). Generally, working capital will have a significant impact on the profitability of a firm, and due to this reason firms commit a large amount of cash on working capital management. It is expected to have an effective management of working capital (Deloof, 2003; Raheman \& Nasr, 2007). Moreover, firms can increase their profit by managing the working capital in efficient ways, i.e. equality in current assets and current liabilities. Working capital management helps to meet the daily obligation, raised within the organizations, and make sure to invest at adequate level in working capital for smooth operations. In absence of adequate working capital, organization can neither operate nor function properly. Hence, continuous efforts are needed for maintaining the balance between current assets and current liabilities to manage working capital (Ahmed et al., 2018).

\footnotetext{
* Lecturer, Faculty of Management Tribhuvan University, Nepal

E-mail: mailtoadhikarisir@gmail.com
} 
Manufacturing firms invest huge amount in working capital comparatively to other firms. So, managers should keep balance between current assets and current liabilities. Tradeoff between current assets and current liabilities at optimum level is essential to honor the short term obligation (Akoto et al., 2013). Manager should be aware about rise in cost due to overinvestment and under-investment in working capital. There are two approach for keeping a tab on working capital by manager. Firstly, the manager should keep optimal cycle as close as possible and should try to avoid any deviation, either in positive or negative. Secondly, manager should keep optimal working capital in relation to cost and benefit tradeoff. Both strategies lead to maximization of profit (Caballero et al., 2012). In ability to maintain optimal level of working capital deteriorate firm's operation and profitability, and there is high possibility of bankruptcy (Ahmed et al., 2018). The degradation of company credit suffers short-term liquidity crisis which leads to ineffective respond to temporary requirement of capital within an organization. And as a consequence of low working capital, organization will lose opportunity to invest in a profitable opportunity (Saghir, 2011). Further, investment on inappropriately managed working capital leads to non-efficiency function of management and increase in opportunity cost (Charitou, 2016).

The necessity of proper management of net current assets is absolutely vital for smooth running of business. Balance between working capital components should be in such a way that the profitability of the company is not compromised (Bhunia, 2010). The objective of a manager should be to create higher value for shareholders, and can be achieved by reducing the number of days' accounts receivable and inventories at the minimum and reasonable level (Deloof, 2003; Falope \& Ajiore, 2009; Mathuva, 2010) and ultimately leads to profitability of the company (Raheman \& Nasr, 2007). Firms can extend their payment to lender as long as they do not damage their relationship with creditors, and firms should reduce the cash conversion cycle at minimum and possible level. This results in gaining or sustaining competitive advantage over competitors through effective and efficient utilization of and organization's resources (Mathuva, 2010). Proper inventory management system helps the companies to avoid over stock, and to stop from piling up of inventory, which results in efficient outcome in investment. There must be collaborative relationship with customers, where payment by them are in short period, and with suppliers, where credit period can be extended (Azam \& Haider, 2011). By reducing account receivables days and maintaining optimal cash conversion cycle level can improve the profitability and increase the value of the firms (Akoto et al., 2013).

Profitability measurement components return on assets and return on equity have negative relationship with the cash conversion cycle (Bagchi \& Khamrui, 2012). This study is conducted based on the previous study, and more importantly it identifies the impact of working capital management on the profitability of the manufacturing firms in the context of Nepal. 


\section{Literature Review}

Previous researchers have studied the impact of profitability on presence of working capital management in the context of different countries, sectors and environments. Some of the useful and gist review of previous literature are mentioned below.

Deloof (2003) used correlation and regression analysis to find the effect on profitability of Belgian firms. The measures of working capital management used for this study are number of days' accounts receivable, inventories and accounts payable and cash conversion cycle and by minimizing them to a reasonable level, managers can create value to their shareholders. Gross operating income is negatively related with number of days' accounts receivable, inventories and accounts payable. Raheman and Nasr (2007) used a sample of 94 Pakistani firms from 1999-2004 which is listed on Karachi Stock Exchange to find the effect on profitability due to working capital. By doing correlation and regression analysis, the study found that there is a strong negative relationship between variables of working capital variables (i.e. average collection period, inventory turnover in days, average payment period and cash conversion cycle) and profitability of the firm, but there is a strong relationship between the size of the firm and profitability. The study strongly suggests to reduce the cash conversion cycle in order to increase the profit of the firm. Nimalathasan (2010) conducted a study where return on assets is used as dependent variable and it is negatively correlated with cash conversion cycle, inventory conversion period and receivable conversion period which suggests that if managers are able to reduce the number of day's inventories and accounts receivable, profitability of manufacturing firms can increase.

To investigate the relationship between working capital management and firm's profitability, Bagchi and Khamrui (2012) used 10 years' data from 2000-2010 of a sample of 10 fast moving consumer goods (FMCG) companies in India. Return on assets has been used to measure the profitability. For analysis of data, Pearson's correlation and pooled ordinary least square regression are used. The study found that cash conversion cycle and debt has significant and negative relationship with firm's profitability. Efficient ways of managing working capital ultimately leads to increase the firm's profitability.

Kumari and Anthuvan (2017) study listed manufacturing sectors in Chennai from 2006 to 2012 , to find the impact on profitability caused by working capital management. Net operating profitability is used as dependent variable to measure profitability. Thirty-four samples of CFO from manufacturing units for primary data and 162 companies are selected from S\&P CNX 500 companies for secondary data. Out of 15 sectors, two sectors are not affected by working capital components whereas other 13 sectors are strong and significant relationship with working capital components, liquidity and profitability.

Ahmed et al. (2017) examined the textile companies to find the impact of working capital management by using the data of eight years from 2007 to 2014 of 22 firms and had used logistic regression to analyze the data. Return on assets (ROA) and return on equity (ROE) are used as dependent variables. Bangladesh's textile companies are dealing with high number 
of inventory and inventory turnover is usually more frequent than accounts payable which leads to purchasing the high number of raw materials in credit. Findings conclude that current ratio and current liabilities have significant impact on profitability of textile companies.

Sathyamoorthi et al. (2018) analyze the effect of working capital management on the profitability of the retail store in Botswana. The study used the data from 2012-2016 of listed retail stores in Botswana Stock Exchange. Descriptive statistics, correlation and regression analysis to find the relationship between the dependent and independent variables. A multiple regression analysis found that Average payment period and current ratio are negatively and significantly related with return on assets, whereas, quick ratio is positively and significantly related with return on assets.

From the above study, ROE, ROA and net operating income are used as measurement of profitability and found that they are negatively related with cash conversion cycle, inventory conversion period, receivables conversion period, and payable conversion period.

\section{Objectives of the study}

In order to analyze the problem statement which is mentioned earlier, this study investigated on the impact of working capital management and its relationship with profitability from a sample of five manufacturing companies. Hence, several objectives are as follows

- To establish the relationship between ICP, RCP, PDP and CCC with the profitability of the selected manufacturing firms.

- To assess the linkage between debt ratio and profitability of the selected manufacturing firms.

- To examine the correlation across current ratio and profitability of the selected manufacturing firms.

\section{Limitations}

The limitations of the study are as follows.

Covers secondary data from 2010/11 to 2017/18.

Since there was no categorization of account payable in balance sheet of 2010/11 annual report of Bottlers Nepal (Balaju) Limited. So, researcher used average portion from next eight-year annual report. Hence, proportion of account payable from current liabilities was $62.88 \%$.

Bottlers Nepal (Terai) Limited had a one year missing, i.e. 2011/12. So, researcher used simple regression to estimate the value of year 2011/12 by using previous six-year data from 2005/06 to $2010 / 11$. Further, $2010 / 11$ and 2011/12 year accounts payable was estimated by using the next six year data from $2012 / 13$ to $2017 / 18$ at proportion of $43.28 \%$.

Operational definition and hypothesis formulation. 
Table 1: Selected variables for study

\begin{tabular}{|c|c|c|}
\hline S. No. & Independent variables & Dependent Variables \\
\hline 1 & Inventory conversion period (ICP) & \\
\hline 2 & Receivable conversion period ( $\mathrm{RCP}$ ) & Return on Equity (ROE) \\
\hline 3 & Payable deferred Period (PDP) & Return on Assets (ROA) \\
\hline 4 & Cash Conversion Cycle (CCC) & Net income (POR) \\
\hline 5 & Debt Ratio (DR) & \\
\hline 6 & Current Ratio (CR) & \\
\hline
\end{tabular}

\section{Inventory conversion period (ICP)}

Inventory conversion period is calculated by dividing inventory by cost of goods sold and multiplying the result with 365 days (Raheman \& Nasr, 2007). It is also time taken by firms to convert inventory into sales (Sathyamoorthi, 2018). Declining sales leads to higher volume of inventory which ultimately end up affecting the profitability of the firms (Deloof, 2003). Various studies have found the negative relationship between the ICP and profitability of the firms (see: Al-Debi'e, 2011; Azam \& Haider, 2011; Affeef, 2011) which suggest that extending ICP leads to decrement of profit. Furthermore, this is proven by the findings of Belgian firms (Deloof, 2003), Pakistan firms (Saghir, 2011), Small and Medium Enterprises performance in Nigeria (2017), Pakistani firms listed in Karachi Stock Exchange (Raheman \& Nasr, 2007) and manufacturing companies in Sri Lanka (Nimalathasan, 2010). Contradictory to this findings, a survey on Kenyan listed firms (Mathuva, 2010) and manufacturing sector in Malaysia (Jakpar et al., 2017) found that ICP and profitability of the firms is positively correlated. Due to overwhelming evidence regarding negative relationship, the hypothesis is formed as,

Ho: Inventory conversion period is inversely related to the profitability of the firms.

\section{Receivable conversion period (RCP)}

Receivable conversion period is calculated by dividing account receivable by sales and multiplying the result by 365 (Raheman \& Nasr, 2007). RCP also called as debtors' conversion period, is the time required to collect the cash from debtors (Nimalathasan, 2010). The purpose of a firm is to minimize the time between the sales and receipt of payment from customer (Falope \& Ajilore, 2009). Most of the studies have found a negative relationship between RCP and profitability, such as 803 listed companies on Bursa Malaysia (Yunos et al., 2018), Pakistan Firms (Saghir, 2011), 30 samples of Nairobi Stock Exchange (Mathuva, 2010), 88 sample of American firms listed on the New York Stock Exchange (Gill et al., 2010) and 10 sample of Fast Moving Consumer Goods (Bagchi \& Khamrui, 2012). So, hypothesis can be formed as,

Ho: Receivable conversion period is inversely related to the profitability of the firms. 
Payable deferral period (PDP)

Payable deferral period is the time taken by firms to pay its creditors (Sathyamoorthi et al., 2018). PDP can be calculated by dividing account receivable by sales and multiplying the results by 365 (Raheman \& Nasr). As a firm, posing amount in free credit from creditors is always the first choice of credit (Flope \& Ajilore, 2009). The evidence from the study concluded that there is a negative relationship between PDP and profitability of the firm (Bagchi \& Khamrual, 2012; Deloof, 2003; Raheman \& Nasr, 2007, Falope \& Ajilore, 2009; Saghir, 2011; Charitou, 2016; Al-Debi'e, 2011). Deloof (2003) found that a firm can get a discount by prompt payment from creditors. Azam \& Haider (2011) found to have significant positive relationship PDP and profitability components i.e. Return on Equity and Return on Assets. This result is consistent with the result of Mathuva (2010). Due to the dominance of negative relationship, hypothesis can be formed as,

Ho: Payable Deferral Period is inversely related to the profitability of the firms.

\section{Cash conversion cycle (CCC)}

Cash conversion cycle is calculated by subtracting the payable deferral period from the sum of inventory conversion period and payable conversion period (Falope \& Ajilore, 2009). It can also be defined as the time difference between the outlay of cash to purchase raw material and inflow of cash due to sales (Yunos et al., 2018). The study finding concluded that there is negative relationship between Cash Conversion Cycle and profitability of the firm (Deloof, 2003; Mathuva, 2010; Bagchi, 2012; Yunos et al., 2018; Flope \& Ajilore, 2009; Saghir, 2011; Azam \& Haider, 2011; Raheman \& Nasr, 2007). But (Akoto et al., 2013; Gill et al., 2010) found that Cash Conversion Cycle have positive relationship with profitability of the firm. For the study, hypothesis is formed as,

Ho: Cash Conversion Cycle is inversely related to the profitability of the firm.

\section{Debt ratio (DR)}

Debt ratio is the ratio of total debt/liabilities to total assets (Jakpar et al., 2017; Raheman \& Nasr, 2007). Proper economic condition within the country leads to increment of profit of the firm even with the increase in debt (Falope \& Ajilore, 2009). But most of the findings are opposite of this relationship. (Jakpar et al., 2017; Raheman \& Nasr, 2007; Dong, 2010; Mohamad, 2010; Charitou, 2016; Al-Debi'e, 2011; Vural et al., 2012) found that there is significantly negative relationship between debt ratio and profitability. Debt is unfavorable affect the firms' profitability and have higher default risk (Charitou, 2016). Such that, following hypothesis is formed,

Ho: Debt ratio is inversely related to the profitability of the firm

\section{Current ratio (CR)}

Current ratio measures the liquidity of the firm and is calculated by dividing current assets by current liabilities (Raheman \& Nasr, 2007; Paul \& Mitra, 2018). Current ratio can be also 
called as liquidity or efficiency ratio because it measures the ability of any firms to fulfill its short-term obligation by current assets. So, it is expected to have higher current ratio for favorable situation where current liabilities can be paid off easily. Finding concluded that, $\mathrm{CR}$ and ROA found to be relatively low positive correlation and significant whereas, CR and ROE found to have significant relationship (Ahmed et al., 2017). There is positive and statistically significant relationship between the current ratio and profitability (Akomeach \& Frimpong, 2019; Akoto et al., 2013; Azam \& Haider, 2011; Kumari \& Anthuvan, 2017). In under-developed capital market, higher current assets may not be destroying the value of shareholders because it can pay off the current liabilities and make short term reinvestment (Akoto et al., 2013). Mohamad, (2010); Sathyamoorth et al., (2018) concluded to have negative relationship between current ratio and profitability. Hence, following hypothesis is formed,

Ho: Current ratio is positively related to the profitability of the firm.

\section{Dependent variables}

The dependent variable for the study is the profitability of the firm. (Al-Abass, 2018; Azam \& Haider, 2011; Ahmed et al., 2017) used ROA and ROE to measure the profitability of the firms. Hence, the study used ROA \& ROE as variables to measure the profitability of manufacturing firms. ROE is also a profitability ratio which is the ratio of net income to total equity. Higher ROE is favorable for the firms and vice versa (Akoto et al., 2013). ROA is the ratio of net income to book value of the assets. It indicates the efficiency of management to convert the institution assets into profit (Falope \& Ajilore, 2009; Saghir, 2011) or measures the efficiency by consuming the assets into net income. More profitable business has higher value of ROA and vice versa (Yuons et al., 2018). Furthermore, (Charitou, 2016; Bagchi \& Kamrual, 2012; Nimalathasan, 2010) used ROA as dependent variable and found comprehensive relationship and obtain meaningful results with other variables.

\section{Methodology}

Descriptive and causal-comparative research design are used as research design in this study. This study used only secondary data, which are retrieved from annual report of five manufacturing companies in Nepal. The sample interval is eight years from 2010/11 to $2017 / 18$ for each manufacturing companies. Such that, statistical tools used in this study for data analysis are Pearson's correlation, linear regression and logistic regression.

Table 2: Selected manufacturing companies

\begin{tabular}{ll}
\hline S. No. & Manufacturing companies \\
\hline 1 & Nepal Lube Oil \\
2 & Himalayan Distillery Limited \\
3 & Bottlers Nepal (Balaju) Limited \\
4 & Bottlers Nepal (Terai) Limited \\
5 & Dabur Nepal \\
\hline
\end{tabular}


For linear regression analysis, dependent variables as return on equity (ROE) and return on asset (ROA), and independent variables as inventory conversion period (ICP), receivable conversion period (RCP), cash conversion cycle (CCC), debt ratio (DR) and current ratio (CR).

Therefore, Model 1 is represented as,

$R O E=\beta_{0}+\beta_{1} I C P+\beta_{2} R C P+\beta_{3} P D P+\beta_{4} C C C+\beta_{5} D R+\beta_{6} C R+e$

And model 2 is represented as,

$R O A=\beta_{0}+\beta_{1} I C P+\beta_{2} R C P+\beta_{3} P D P+\beta_{4} C C C+\beta_{5} D R+\beta_{6} C R+e$

Where, $\beta_{0}=$ constant term, $\beta_{1}, \beta_{2}, \beta_{3}, \beta_{4,}, \beta_{5}, \beta_{6}=$ beta coefficient of independent variables, $e=$ error term

For binary logistic regression analysis, the dependent variable as net income (POR) and independent variable as inventory conversion (ICP), receivable conversion period (RCP), payable deferred period (PDP), debt ratio (DR) and current ratio (CR). According to Karkwah et al. (2019); Mernard (1995), suppose $\mathrm{D}_{\mathrm{i}}$ is the working capital (i.e. current assets) of $\mathrm{i}^{\text {th }}$ for the manufacturing firm for $t$ years and $\mathrm{K}_{\mathrm{i}}$ is $\mathrm{i}^{\text {th }}$ manufacturing firm's profit for eight years. So, average value $\left(\mathrm{h}_{\mathrm{i}}\right)$ of $\mathrm{i}^{\text {th }}$ is calculated as:

$h_{i}=\underline{K}_{i}$ ss. $t(i=1,2,3 . n)$ for $t$ years

Where, $\mathrm{n}$ is the total number of firms who had acquired profit in the last $\mathrm{t}$ years,

$$
\text { Let, } R_{j}=\underline{D}_{i}(i=1,2,3 \ldots n)
$$

then, manufacturing firm are able to have managed working capital on profit if $R_{j}>1$.

So, $\mathrm{i}^{\text {th }}$ manufacturing firm, this study defined a dichotomous or binary variable as POR. For estimation purpose of binary logistic regression model can be explained by the following equation,

$\mathrm{POR}=\beta_{0}+\beta_{7} \mathrm{ICP}+\beta_{8} \mathrm{RCP}+\beta_{9} \mathrm{PDP}+\beta_{10} \mathrm{CCC}+\beta_{11} \mathrm{DR}+\beta_{12} \mathrm{CR}$

Where, POR is net income

Here, binary logistic regression specifies that,

$\mathrm{POR}=1$ if $\mathrm{R}_{\mathrm{j}}>1$

0 if $R_{j}<1$

So, Probability of company to be profitable

$$
\begin{aligned}
& \mathrm{P}(\mathrm{Y}=1)=\exp \left\{\beta_{\underline{0}}+\beta_{\underline{\underline{z}}} \underline{\mathrm{ICP}+} \beta_{\underline{\underline{8}}} \underline{\mathrm{RCP}+} \beta_{\underline{\underline{9}}} \underline{\mathrm{PDP}+} \beta_{\underline{10}} \underline{\mathrm{CCC}}+\beta_{\underline{11}} \underline{\mathrm{DR}+} \beta_{12} \underline{\mathrm{CR}}\right\} \\
& 1+\exp \left\{\beta_{0}+\beta_{7} \mathrm{ICP}+\beta_{8} \mathrm{RCP}+\beta_{9} \mathrm{PDP}+\beta_{10} \mathrm{CCC}+\beta_{11} \mathrm{DR}+\beta_{12} \mathrm{CR}\right\}
\end{aligned}
$$




\section{DATA ANALYSIS}

Descriptive statistics and correlation

\section{Table 3}

Descriptive statistics and correlation with respect of $\mathrm{ROE}$

\begin{tabular}{|c|c|c|c|c|c|c|c|c|c|c|c|c|}
\hline & $\mathrm{N}$ & Min & Max & Mean & Std. Dev & ROE & ICP & RCP & PDP & CCC & $\overline{D R}$ & CR \\
\hline$\overline{\mathrm{ROE}}$ & 40 & -0.1167 & 0.5308 & 0.23145 & 0.1292 & 1 & & & & & & \\
\hline ICP & 40 & 9.8 & 174.7 & 106.72 & 33.0893 & $\begin{array}{l}-0.303^{*} \\
.058\end{array}$ & 1 & & & & & \\
\hline $\mathrm{RCP}$ & 40 & .4 & 211.1 & 60.804 & 57.1151 & $\begin{array}{l}-0.107 \\
.510\end{array}$ & $\begin{array}{l}0.506^{* * *} \\
.001\end{array}$ & 1 & & & & \\
\hline PDP & 40 & 20.3 & 770.4 & 157.934 & 132.0534 & $\begin{array}{l}0.284^{*} \\
.076\end{array}$ & $\begin{array}{l}0.393^{* *} \\
.012\end{array}$ & $\begin{array}{l}0.557^{* * *} \\
.000\end{array}$ & 1 & & & \\
\hline $\mathrm{CCC}$ & 40 & -471.9 & 130.1 & 9.590 & 108.9712 & $\begin{array}{l}-0.492^{* * *} \\
.001\end{array}$ & $\begin{array}{l}0.092 \\
.572\end{array}$ & $\begin{array}{l}0.003 \\
.984\end{array}$ & $\begin{array}{l}-0.801^{* * *} \\
.000\end{array}$ & 1 & & \\
\hline DR & 40 & 0.2927 & 0.1443 & 0.64876 & 0.1879 & $\begin{array}{l}-0.101 \\
.381\end{array}$ & $\begin{array}{l}0.254 \\
.113\end{array}$ & $\begin{array}{l}0.236 \\
.143\end{array}$ & $\begin{array}{l}0.526^{* * *} \\
.001\end{array}$ & $\begin{array}{l}-0.425^{* * *} \\
.006\end{array}$ & 1 & \\
\hline CR & 40 & .3 & 3.2 & 1.048 & 4996 & $\begin{array}{l}-0.101 \\
.534 \\
\end{array}$ & $\begin{array}{l}-0.074 \\
.651 \\
\end{array}$ & $\begin{array}{l}0.105 \\
.517 \\
\end{array}$ & $\begin{array}{l}-0.3^{*} \\
.060 \\
\end{array}$ & $\begin{array}{l}0.396^{* *} \\
.011\end{array}$ & $\begin{array}{l}-0.339^{* *} \\
.032\end{array}$ & 1 \\
\hline
\end{tabular}

${ }^{* * *} \mathrm{p}<0.01 ;{ }^{* *} \mathrm{p}<0.05 ;{ }^{*} \mathrm{p}<0.10$

Table 3 shows the descriptive statistics and correlation with respect to ROA. Dependent variable is return on equity and independent variables are inventory turnover period, receivable turnover period, payable deferred period, cash conversion cycle, debt ratio and current ratio. From descriptive statistics of sampled manufacturing firms, the average ROE of the manufacturing firms is $23.14 \%$ with maximum value of manufacturing firm reach to as high as $53.08 \%$ and as low as $-11.67 \%$. While, its standard deviation is only $12.93 \%$ indicating that there is not much deviation from maximum and minimum value. Average inventory conversion period value is 106.72 days indicating that manufacturing firms are inefficient in converting inventory into finished goods and selling it to consumers. Value of ICP reach as high as 174.7 days and as low as 9.8 days and its standard deviation is 33.0893 days. Likewise, average receivable conversion period of manufacturing firms is 60.804 days indicating a satisfactory in converting receivables amount into cash. Value of RCP reach as high as 211.1 days and as low as 0.4 days, while standard deviation is 57.11511 days from maximum and minimum value. Average payable deferred period of manufacturing firms is 157.934 days indicating a satisfactory position in terms of purchasing materials and labors, and payment of cash. Such that, manufacturing firms have PDP value as high as 770.4 days and as low as 20.3 days, and standard deviation of 132.05 days. This is the strong position in perspective of debtors. Similarly, average value of cash conversion cycle is 9.59 days indicating that manufacturing firms are very efficient in converting their cash on hand into inventory and account payable, through sales and accounts receivable, and then back into cash again. While, 
value of cash conversion cycle of manufacturing firms reaches as high as 130.1 days and as low as -471.9 days, and standard deviation of 108.97 days show that there is severe deviation from the maximum and minimum values. Average debt ratio of manufacturing firms is $64.88 \%$ indicating a high portion of debt in comparison to total assets. Here, level of debt ratio is as high as $144.27 \%$ and as low as $29.27 \%$, and standard deviation is $18.79 \%$ showing not much deviation from minimum and maximum values. The average current ratio of manufacturing firms is 1.048 indicating very efficient balance between current asset and current liabilities. In addition, current ratio is as high as 3.2 and as low as 0.3 , and standard deviation is 0.4996 (i.e. $49.96 \%$ ) which is a very big deviation from maximum and minimum value. From correlation table, ROE and ICP is negatively correlated (-0.303) and moderately significant at p-value less than 10 percent. Likewise, there is negative correlation between ROE and PDP with the value of -0.284 at moderately significant. Similarly, there is a negative correlation between ROE and CCC with the value of -0.492 at highly significant level, i.e. $\mathrm{p}$-value less than $1 \%$.

Table 4: Descriptive statistics and correlation with respect to ROA

\begin{tabular}{|c|c|c|c|c|c|c|c|c|c|c|c|c|}
\hline & $\mathrm{N}$ & Min & Max & Mean & Std. Dev & ROA & ICP & $\mathrm{RCP}$ & PDP & $\mathrm{CCC}$ & DR & CR \\
\hline$\overline{\mathrm{ROA}}$ & 40 & -0.0442 & 0.3267 & 0.0912 & 0.7323 & 1 & & & & & & \\
\hline ICP & 40 & 9.8 & 174.7 & 106.72 & 33.0893 & $\begin{array}{l}-0.413^{* * *} \\
.008\end{array}$ & 1 & & & & & \\
\hline $\mathrm{RCP}$ & 40 & .4 & 211.1 & 60.804 & 57.1151 & $\begin{array}{l}-0.394^{* *} \\
.012\end{array}$ & $\begin{array}{l}0.506^{* * *} \\
.001\end{array}$ & 1 & & & & \\
\hline PDP & 40 & 20.3 & 770.4 & 157.934 & 132.0534 & $\begin{array}{l}-0.117 \\
.472\end{array}$ & $\begin{array}{l}0.393^{* *} \\
.012\end{array}$ & $\begin{array}{l}0.557^{* * *} \\
.000\end{array}$ & 1 & & & \\
\hline CCC & 40 & -471.9 & 130.1 & 9.590 & 108.9712 & $\begin{array}{l}-0.19 \\
.240\end{array}$ & $\begin{array}{l}0.092 \\
.572\end{array}$ & $\begin{array}{l}0.003 \\
.984\end{array}$ & $\begin{array}{l}-0.801^{* * *} \\
.000\end{array}$ & 1 & & \\
\hline DR & 40 & 0.2927 & 0.1443 & 0.6488 & 0.1879 & $\begin{array}{l}0.142 \\
.122 \\
0.208 \\
.197 \\
\end{array}$ & $\begin{array}{l}0.254 \\
.113 \\
-0.074 \\
.651 \\
\end{array}$ & $\begin{array}{l}0.236 \\
.143 \\
0.105 \\
.517 \\
\end{array}$ & $\begin{array}{l}0.526^{* * *} \\
.001 \\
-0.3^{*} \\
.060\end{array}$ & $\begin{array}{l}-0.425^{* * *} \\
.006 \\
0.396^{* *} \\
.011\end{array}$ & $\begin{array}{l}-0.339^{* *} \\
.032\end{array}$ & 1 \\
\hline
\end{tabular}

${ }^{* * *} \mathrm{p}<0.01 ;{ }^{* *} \mathrm{p}<0.05 ;{ }^{*} \mathrm{p}<0.10$

Table 4 shows the descriptive statistics and correlation with respect to ROA. Dependent variable is return on assets and independent variables are inventory turnover period, receivable turnover period, payable deferred period, cash conversion cycle, debt ratio and current ratio. From descriptive statistics of sampled manufacturing firms, average ROA of manufacturing firms is $9.12 \%$ with ROE value as high as $32.67 \%$ and as low as $-4.42 \%$, and standard deviation of $7.32 \%$ indicating not much deviation from maximum and minimum value. From correlation table, there is a negative correlation between ROA and ICP $(-0.4133)$ and it is highly significant at $\mathrm{p}$-value less than $1 \%$. Likewise, there is a negative correlation between ROA and RCP (-0.394) and it is significant at p-value less than $5 \%$.

From table 1 and 2, since the maximum value of PDP is 770.4 days and standard deviation of 132.12 days, ROA and ROE is highly affected by PDP due to greater fluctuation of value over 
a period of time. Similarly, minimum value of CCC is -471.27 days and standard deviation is 108.87 days. Due to higher volatility in value, it shows that ROA and ROE are significantly influenced by CCC. Further, debt ratio and current ratio greatly affect ROA and ROE because the fluctuation of DR and CR is high. Debt ratio and current ratio of manufacturing firm reach as high as $144.27 \%$ and 3.2(320\%) respectively. ICP, PDP and CCC are negatively correlated with ROE, whereas ICP and RCP are also negatively correlated with ROA.

Ordinary linear regression

Table 5: OLS regression table for ROE

\begin{tabular}{ccccc}
\hline & \multicolumn{2}{c}{ Unstandardized coefficients } & & \\
\cline { 2 - 3 } Model & $\mathrm{B}$ & Std. Error & $\mathrm{t}$ & Sig. \\
\hline (Constant) & 31.238 & 10.692 & 2.922 & .006 \\
ICP & -.104 & .067 & -1.543 & .132 \\
RCP & .003 & .039 & .083 & .934 \\
CCC & -.058 & .020 & -2.884 & .007 \\
DR & .018 & .117 & .155 & .878 \\
CR & 2.070 & 4.207 & .492 & .626 \\
Adjusted R square & 0.214 & & Sig. F & 0.02 \\
Std. Error & 11.46 & & Durban Watson & 1.631 \\
\hline
\end{tabular}

An ordinary linear regression analysis was performed to test the significance of the relationship between profitability of manufacturing firms measured by ROE and ROA as independent variables and other independent variables as ICP, RCP, PDP, CCC, DR and CR.

Regarding ROE as dependent variable which is presented in table 5, SPSS automatically excluded or dropped PDP as it was perfectly correlated with another independent variable (i.e. CCC) and only five variables were carried for regression analysis. The model was first tested for goodness of fit using the r-squared value which retained value of 0.315 . It shows that $31.5 \%$ of the variation in ROE is explained by the five variables; ICP, RCP, CCC, DR and CR. Further, it is supported by significant F statistics value, 0.019999. The regression output shows that only one variable out of five variables is significant $(\mathrm{P}$-value $<0.05)$. Profitability as measured by ROE is found to be negatively related with cash conversion cycle (CCC) with p-value of 0.007 , and beta coefficient of CCC is -0.058

Table 6: OLS regression table for ROA

\begin{tabular}{|c|c|c|c|c|}
\hline & \multicolumn{2}{|c|}{ Unstandardized coefficients } & \multirow[b]{2}{*}{$\mathrm{t}$} & \multirow[b]{2}{*}{ Sig. } \\
\hline Model & $\mathrm{B}$ & Std. Error & & \\
\hline (Constant) & -.952 & 5.001 & -.190 & .850 \\
\hline ICP & -.064 & .031 & -2.034 & .050 \\
\hline $\mathrm{RCP}$ & -.054 & .018 & -2.978 & .005 \\
\hline $\mathrm{CCC}$ & -.008 & .009 & -.862 & .395 \\
\hline DR & .204 & .055 & 3.720 & .001 \\
\hline $\mathrm{CR}$ & 6.688 & 1.968 & 3.399 & .002 \\
\hline $\begin{array}{l}\text { Adjusted R square } \\
\text { Std. Error }\end{array}$ & $\begin{array}{l}0.464 \\
5.36\end{array}$ & & $\begin{array}{l}\text { Sig. } \\
\text { Durban Watson }\end{array}$ & 2.041 \\
\hline
\end{tabular}


Regarding dependent variable as ROA which is presented in table 6, SPSS automatically excluded PDP variable due to perfect collinearity with CCC variable and only five variables are considered for regression analysis; ICP, RCP, CCC, DR and CR. Test for goodness of fit using r-squared value shows the value as 0.533 . It indicates that $53.3 \%$ of variation in independent variable ROA is explained by five variables. Further, it is supported by $\mathrm{F}$ statistics value whose value is significant at 0.000059 . The regression output shows that out of five independent variables, four of them are significantly related with dependent variable ROA; ICP, RCP, DR and CR (p-value<0.05). Firstly, a negative and significant relationship was found between the return on assets and inventory conversion period at $p$-value of 0.05 . The beta coefficient of ICP is found to be -0.064 , which means increase in ICP by $1 \%$ leads to decrease in profit, i.e. ROE, by $0.00064 \%$. Secondly, a negative and significant relationship was found between the return on assets and RCP ( $p$-value $=0.005$ ). While, beta coefficient was found to be -0.054 , which means increase in $1 \%$ of RCP leads to decrease in return on assets by $0.00054 \%$. Thirdly, there is a positive and significant relationship between return on assets and debt ratio at $\mathrm{p}$-value of 0.001 . And beta coefficient of 0.204 indicates that increase in debt ratio by $1 \%$ leads to increase in profit, which is ROA, by $0.00204 \%$. Lastly, profitability as measured by ROA found to be positively and significantly related with current ratio at p-value of 0.002 . Beta coefficient of CR indicate that increase in current ratio by $1 \%$ leads to increase in ROA by $0.06688 \%$.

Table 7: Binary Logistic regression

\begin{tabular}{|c|c|c|c|c|c|c|}
\hline Model & $\mathrm{B}$ & $\mathrm{Df}$ & Sig. & $\operatorname{Exp}(B)$ & Wald & S.E. \\
\hline ICP & .016 & 1 & .297 & 1.017 & 1.090 & .016 \\
\hline $\mathrm{RCP}$ & .028 & 1 & .060 & 1.028 & 3.544 & .015 \\
\hline PDP & -.008 & 1 & .053 & .992 & 3.750 & .004 \\
\hline DR & .077 & 1 & .087 & 1.080 & 2.933 & .045 \\
\hline & 1.188 & 1 & .227 & 3.279 & 1.457 & .984 \\
\hline (Constant) & -7.428 & 1 & .049 & .001 & 3.862 & 3.780 \\
\hline \multicolumn{2}{|c|}{$\begin{array}{l}\text { Cox \& Snell R-Square } \\
\text { Nagelkerke R-Square }\end{array}$} & & & -2 log likelihood & 33.402 & \\
\hline & \multirow{2}{*}{\multicolumn{2}{|c|}{$\begin{array}{c}\text { Chi square } \\
19.523\end{array}$}} & & \multirow{2}{*}{$\begin{array}{c}\text { Df } \\
5\end{array}$} & \multicolumn{2}{|l|}{ Sig } \\
\hline Step & & & & & .002 & \\
\hline Block & \multicolumn{2}{|c|}{19.523} & & 5 & \multicolumn{2}{|l|}{.002} \\
\hline Model & \multicolumn{2}{|c|}{19.523} & & 5 & .002 & \\
\hline
\end{tabular}

Binary logistic regression is used when the dependent variable is binary or dichotomous. Such that, this study used Karkwah et al. (2019); Mernard (1995) approach to equate profit or net income (POR) as a binary variable. So, dependent variable in binary logistic regression is POR, whereas independent variables are ICP, RCP, PDP, CCC, DR and CR. Due to collinearity effect between PDP and CCC, SPSS automatically dropped CCC variable. As presented in table 7, there is a moderately significant and positive relationship between RCP and POR which indicate that with increase in 1 unit of RCP leads to an increase in POR by 1.028. Likewise, there is moderately significant and negative relationship between PDP and POR, which means increase in 1 unit of PDP leads to decrease in 1.028 unit of POR. Further, DR is 
moderately significant and positively related with profitability as POR. Increase in 1 unit of DR leads to increase in 1.080 unit of profitability as POR. Results reveal that RCP, PDP and DR are significant variables of working capital management that significantly impact the profitability of a manufacturing firm.

\section{Discussion of results}

ICP shows a negative and moderately significant relationship with ROE, while negative and highly significant relationship with ROA $(-0.413$ at $\mathrm{p}$-value $=0.008)$. Further, linear regression analysis found beta coefficient of ICP value as -0.064 , which is negative and significantly related with ROA. Thus, hypothesis is accepted and it is consistent with the findings of (Azam \& Haider, 2011; Raheman \& Nasr, 2007; Deloof, 2003). It implies that manufacturing companies will increase the profitability by decreasing the inventory conversion period.

The study showed negative and significant correlation between RCP and ROA, and supported by linear equation with shows the negative and significant relationship. But there is a positive relationship between ROE and RCP linear regression but insignificant, however, binary logistic regression results a positive and moderately significant ( $\mathrm{p}$-value $=0.06$ ) relationship between ICP and POR. Since, binary logistic is more standard form of statistical tools, thus, this study selects alternative hypothesis, RCP is positively related with profitability of a manufacturing firm and it is not consistent with the findings found by Saghir (2011); Mathuva (2010) and Jakpar et al. (2017). Similarly, there is positive and moderately significant relationship between PDP and ROE at p-value of 0.076. In contrast to this, binary logistic regression resulted the negative and moderately significant relationship at $\mathrm{p}$-value of 0.053 . Thus, the null hypothesis is accepted, this means, manufacturing companies should decrease PDP in order to increase the profitability of a company. This finding is consistent with the findings of Baagchi and Khamrual (2012); Deloof (2003) and Charitou (2016).

The results of correlation found that there is negative and highly significant relationship between ROE and CCC (-0.492 at p-value $=0.001)$. Further, beta coefficient of CCC is negative and highly significant. This finding is similar to the findings of Deloof (2003) and Gill et al. (2010). Manufacturing company will increment their profitability by decrement of CCC. Likewise, ordinary linear regression between CR and ROA indicate that there is positive beta coefficient, i.e. 6.688, and highly significant. Thus, the null hypothesis is accepted and suggests that in order to increase the profitability of a company, they should increase the current ratio. Akomeach and Frimpong (2019); Akoto et al. (2013); Azam and Haider (2011) found similar findings which are consistent with this study. Similarly, the beta coefficient of DR is positive (+0.204) and highly significant in relation to ROA (p-value of 0.0010 , and further it is supported by binary logistic linear regression which result in beta coefficient of 0.077 at moderately significant ( $\mathrm{p}$-value $=0.087$ ) in relation to POR. Thus, alternative hypothesis is selected which indicates increase in DR leads to increase in profitability of a manufacturing company. It is consistent with the findings of (Falope \& Ajilore, 2009). There are enough evidence from this study to conclude the direction of influence by each variable with respect to profitability of manufacturing companies or firms. 


\section{Conclusion}

This paper focused on the impact of working capital management on profitability of manufacturing firms in Nepal. This study will assist the future researchers, policy and strategy makers, investors and management team to effectively manage the working capital components and its value to profitability position of a manufacturing firm.

After analyzing the eight years' data of 5 manufacturing companies in Nepal, inventory conversion period, receivable conversion period, payable conversion period, cash conversion period, debt ratio and current ratio significantly impact the profitability of a manufacturing company. With stable economic conditions, rise in debt ratio and current ratio does help to generate higher levels of profit, and certain level of receivables conversion period helps to increase sales volume which ultimately increase profit. Average value of payable deferred period endorse the negative relationship, extending payment of supplier deteriorate the relationship with them and foregoing discount amount leads to decrease in profitability. In essence, it is vital to maintain a suitable level of working capital in order to obtain greater amount of profit because this study concludes that about one fourth of the variation in profit earned by a manufacturing company is determined by working capital management.

Since, this study only includes only five manufacturing companies, future research should investigate by supplementing more number of companies and must include more variables such as cash, marketable securities, gross operating profit, firm size and economic growth. Despite some limitations, this study provides a profound understanding of the impact of working capital management on profitability of manufacturing firms in Nepal.

\section{References}

Ahmad, B., Ahmed, I., \& Samim, M. M. (2018). Working capital management efficiency and corporate governance in manufacturing sector of Pakistan. European Online Journal of Natural and Social Sciences, 7(1), 67-86.

Ahmed, S., Mahtab, N., Islam, N., \& Abdullah, M. (2017). Impact of working capital management on profitability: A study on textile companies of Bangladesh. Journal of Business \& Financial Affairs, 6, 292. doi: 10.4172/2167-0234.1000292

Akoto, R. K., Awunyo-Vitor, D., \& Angmor, P. L. (2013). Working capital management and profitability: Evidence from Ghanaian listed manufacturing firms. Journal of Economics and International Finance, 5(9), 373-379.

Al-Abass, H. S. (2018). Effect of working capital management on profitability of cement sector listed companies. International Journal of Academic Research in Accounting, Finance and Management Sciences, 8(1), 137-142. doi: 10.6007/IJARAFMS/v8-i1/3927

Azam, D. M., \& Haider, S. I. (2011). Impact of working capital management on firms' performance:Evidencefromnon-financialinstitutions of KSE-30index.Interdisciplinary Journal of Contemporary Research in Business, 3(5), 481-492. 
Bagchi, B., \& Khamrui, B. (2012). Relationship between working capital management and profitability: A study of selected FMCG companies in India. Business and Economics Journal.

Ba $\tilde{n}_{\text {os-Caballero, S., Garc }}{ }^{i}$ a-Teruel, P. J., \& Mart ${ }^{i}$ nez-Solano, P. (2011). How does working capital management affect the profitability of Spanish SMEs? Small Business Economics, 39(2), 517-529.

Bhunia, D. A. (2010). A trend analysis of liquidity management efficiency in selected private sector Indian steel industry. International Journal of Research in Commerce E Management, 1(5), 48-54.

Charitou, M. S. (2016). The effect of working capital management on firm's profitability: empirical evidence from an emerging market. Journal of Business $\mathcal{E}$ Economics Research, 14(3), 111-118.

Darkwah, K. A., Nortey, E. N. N., Asare-Kumi, A. A., \& Asare, K. (2019). An estimation of working capital management on profit using logistic regression and discriminant analysis. Journal of Economics, Management and Trade, 23(4), 1-9.

Deloof, M. (2003). Does working capital management affect profitability of Belgian firms? Journal of Business Finance and Accounting, 3, 573-587.

Falope, O. I., \& Ajilore, O. T. (2009). Working capital management and corporate profitability: Evidence from panel data analysis of selected quoted companies in Nigeria. Research Journal of Business Management, 3(3), 73-84.

Jakpar, S., Tinggi, M., Siang, T., Johari, A., Myint, K., \& Sadique, M. (2017). Working capital management and profitability: Evidence from manufacturing sector in Malaysia. Journal of Business E Financial Affairs, 6, 255. doi: 10.4172/2167-0234.1000255

Kumari, N. N., \& Anthuvan, V. L. (2017). A study on the impact of the working capital management on the profitability of the leading listed manufacturing companies of Chennai (2006-2012). International Journal of Research in Management, Economics and Commerce, 7(8), 68-87.

Mathuva, D. M. (2010). The influence of working capital management components on corporate profitability: A survey on Kenyan listed firms. Research Journal of Business Management, 4, 1-11.

Menard, S. (1995). Applied logistic regression analysis. In Sage University Paper Series on Quantitative Applications in the Social Sciences, 7-106

Nimalathasan, B. (2010). Working capital management and its impact on profitability: A study of selected listed manufacturing companies in Sri Lanka. Information Management, 12, 76-82.

Raheman, A., \& Nasr, M. (2007). Working capital management and profitability - Case of Pakistani firms. International Review of Business Research Papers, 3(1), 279-300. 
Saghir, A. (2011). Working capital management and profitability: Evidence from Pakistan firms. Interdisciplinary Journal of Contemporary Research in Business, 3(8), 1092-1105.

Sathyamoorthi, C. R., Mapharing, M., \& Selinkie, P. (2018). The impact of working capital management on profitability: Evidence from the listed retail in Botswana. Applied Finance and Accounting, 4(1), 82-94. doi:10.11114/afa.v4i1.2949

Vural, G., Sokmen, A. G., \& Cetenak, E. H. (2012). Effects of working capital management on firm's performance: Evidence from Turkey. International Journal of Economics and Financial Issues, 2(4), 488-495.

Yunos, R. M., Ghapar, F. A., \& Ahmad, S. A. (2018). Working capital management and its effect on profitability: Empirical evidence from Malaysian capital market. Insight Journal, 1(1), 71-87. 